\title{
Outbreaks of meningococcal meningitis in non-African countries over the last 50 years: a systematic review
}

Femke van Kessel ${ }^{1}$, Caroline van den Ende ${ }^{1}$, Anouk M Oordt-Speets ${ }^{1}$, Moe H Kyaw ${ }^{2}$
${ }^{1}$ Pallas Health Research and Consultancy, Rotterdam, the Netherlands
${ }^{2}$ Sanofi Pasteur, Swiftwater, Pennsylvania, USA

\begin{abstract}
Background Meningococcal disease is caused by the bacteria Neisseria meningitidis, leading to substantial mortality and severe morbidity; with serogroups A, B, C, W135, X and Y most significant in causing disease. An outbreak is defined as multiple cases of the same serogroup occurring in a population over a short time-period. A systematic review was performed to gain insight into outbreaks of meningococcal disease and to describe the temporal pattern over the last 50 years in non-African countries.
\end{abstract}

Methods PubMed and EMBASE were searched for English-language publications on outbreaks of meningococcal disease in non-African countries between January 1966 and July 2017, with an additional grey literature search. Articles and reports were considered eligible if they reported confirmed meningococcal outbreak cases, included the region, number of cases, and the start and end dates of the outbreak. Data on outbreaks was stratified by geographical region in accordance with the World Health Organization (WHO) regional classification, and case-fatality rates (CFRs) were calculated.

Results Of the identified publications, 3067 were screened and 73 included, reporting data from 83 outbreaks. The majority of outbreaks were identified in the regions of the Americas (41/83 outbreaks), followed by the European region (30/83 outbreaks). In each of the Western Pacific, Eastern Mediterranean, and South-East Asian regions there were $<10$ outbreaks reported. The predominant serogroup in the majority of outbreaks was serogroup C (61\%), followed by serogroup B (29\%), serogroup A (5\%) and serogroup W135 (4\%). Outbreaks showed a peak in the colder months of both the Northern and Southern Hemispheres. Of the 54 outbreaks where CFR was calculable for all outbreak cases, it ranged from 0\%-80\%.

Conclusions These data present a retrospective view of the patterns for meningococcal disease outbreaks in non-African countries, and provide valuable data for monitoring future changes in disease epidemiology and informing preventive measures.

\section{Correspondence to:}

Moe H. Kyaw

900 Ridgebury Road

Ridgefield CT 06877

USA

MKyaw11@gmail.com
Meningococcal disease is caused by invasive infection by Neisseria meningitidis bacteria. It is an unpredictable, contagious disease that leads to substantial mortality and severe morbidity, with long-term sequels including limb loss, hearing loss, and brain damage [1]. There are two clinical forms of meningococcal disease; meningococcal meningitis, inflammation of the meninges, and meningococcal septicemia, systemic infection of the blood with subsequent shock and disseminated 
intravascular coagulation, which has a much higher fatality rate [2]. The number of cases of meningococcal meningitis worldwide has been estimated to be at least 1.2 million per annum, with a round 135000 deaths [1]. With the use of prompt antibiotic treatment in recent years, the case-fatality rate (CFR) has reduced to $10 \%-20 \%$ from $70 \%-85 \%$ in pre-antibiotic eras $[1,3]$, with serious and long-term sequelae occurring in 10\%-20\% of survivors [4]. Although meningococcal disease frequently occurs as scattered, apparently unrelated cases or in small outbreaks, in some regions this endemic situation may alternate with devastating, unpredictable epidemics. This is the case in the African Meningitis Belt (stretching from Ethiopia to Senegal), which has the highest incidence of meningococcal disease in the world $[1,3,5]$. The incidence of meningococcal disease is generally highest in infants under one year old, with another peak in adolescents and young adults [3,6].

Thirteen serogroups of $N$. meningitidis have been characterized, with serogroups A, B, C, W135, X and Y most significant in terms of causing disease [1]. The serogroup responsible for meningococcal disease cases varies over time and by geographical area [7]. The prevention of meningococcal disease is through the use of vaccination, either as routine immunization, or vaccination at times of outbreaks or epidemics. Polysaccharide vaccines against serogroups A, C, Y and W135 have been available since the 1970s and 1980s, however these elicit a poor, short-lived, immunological response, particularly in those less than two years of age [7]. In more recent years, conjugated vaccines have been introduced, these are available as monovalent (A or C) or tetravalent (A, C, Y, W135) vaccines [7]. Only since 2013 have vaccines against serogroup B become available, due to challenges in identifying target antigens [8]; since 2015 they have been used in routine immunization of infants in the UK [9], and for at-risk individuals aged $\geq 10$ years in the US [10]. Immunization protocols against meningococcal disease vary by country $[3,11,12]$, driven by local patterns of disease.

In the African meningitis belt, the WHO definition of a meningococcal epidemic is $>100$ cases/100 000 population/yeaer [5]. Outside the meningitis belt, where meningococcal disease occurs less frequently, an outbreak is defined as multiple cases of the same serogroup occurring in a defined population over a short time period [11]. Meningococcal disease outbreaks can have a significant burden on health care utilization and costs, in both the short- and long-term [13-17]. Limited data however are currently available on meningococcal outbreaks, which are very useful in helping to understand the burden of meningococcal disease on patients and society, and to inform public health strategies. The aim of this systematic review is to describe the temporal pattern and nature of outbreaks of meningococcal disease reported over the last 50 years. As the disease pattern in the meningitis belt is very different from other countries, with frequent epidemics, the current review focuses on meningococcal outbreaks in non-African countries.

\section{METHODS}

The study protocol for this systematic review was registered to PROSPERO, CRD42017074957 [18], and followed the Preferred Reporting Items for Systematic reviews and Meta-Analyses (PRISMA) guidelines.

\section{Identification of eligible publications}

The PubMed and EMBASE databases were searched for articles on outbreaks of meningococcal disease published between January 1966 and July 2017 (search terms listed in Table S1 in Online Supplementary Document); an additional search of the grey literature using the terms 'meningococcal' and 'outbreak' was conducted in September 2017 which included the websites of ProMED mail, the World Health Organization (WHO), the Centers for Disease Control and Prevention (CDC) and the European Centre for Disease Prevention and Control (ECDC) (Table S1 in Online Supplementary Document).

Articles and reports were considered eligible if they were written in English language, reported clinically or laboratory confirmed meningococcal outbreak cases (as defined in each identified study), included the region of outbreak, number of cases, and the start and end date of the outbreak. Exclusion criteria included: non-relevant publication types (such as expert opinions, letters to the editor, editorials, comments, narrative reviews, or case reports), modeling studies that did not provide original data, genetic carriage studies, animal studies, studies on outbreaks in the African region, studies which focused on a subgroup of outbreak cases, studies where it was unclear whether all outbreak cases were described, general incidence/prevalence studies without a focus on outbreaks, or studies describing a meningococcal epidemic. To prevent inclusion of multiple publications on the same outbreak, only the most recent or most complete publication was selected. The reference list of meta-analyses and good quality systematic reviews were also checked for possibly missed relevant articles. 


\section{Study screening}

Screening of peer-reviewed publications was conducted first on the title and abstract, followed by screening of the full-text article. The first 30\% of titles and abstracts, and the first 10\% of the full-text articles were screened in duplicate, the results were compared and discussed and any disagreements were adjudicated by a third, and if necessary fourth, researcher until consensus was reached. During the screening process there was less than $5 \%$ discrepancy between the two researchers.

Results from ProMED mail were first screened based on title and abstract, followed by full-text screening, as with the peer-reviewed articles. All search hits from the other websites were fully screened, except for the WHO website, for which only the first page of search results was screened in addition to an overview page mentioning all meningococcal outbreaks worldwide in the last 50 years.

\section{Data extraction}

Data from peer-reviewed studies were extracted into a table in MS Word (Microsoft Inc, Seattle, WA) by one researcher, in close collaboration with a second researcher. A separate data extraction table was used for the grey literature. Information identified from the studies included study design, study characteristics (ie, country, study population and setting, outbreak period, source of outbreak), case detection and definition, and data on the meningococcal outbreak (ie, number of cases, age/gender, N. meningitidis serogroup, outcomes of the outbreak, control intervention). All data extraction tables were then reviewed by a second researcher. As most studies were not of a classical design suited to appraisal using existing checklists, no checklists were used to assess the quality of the articles or to calculate a total quality score. Nevertheless, some articles were excluded because of major limitations in their design or reporting of outbreaks, and included in the category 'Description of outbreak unclear or incomplete'.

\section{Outcomes}

Data on outbreaks were visualized by timelines and stratified by geographical region in accordance with the WHO regional classification (the region of the Americas (stratified for North and South American countries), South-East Asia region, European region, Eastern Mediterranean region (including Israel), and the Western Pacific region). The identified dates of each outbreak allowed assessment of the seasonal pat-

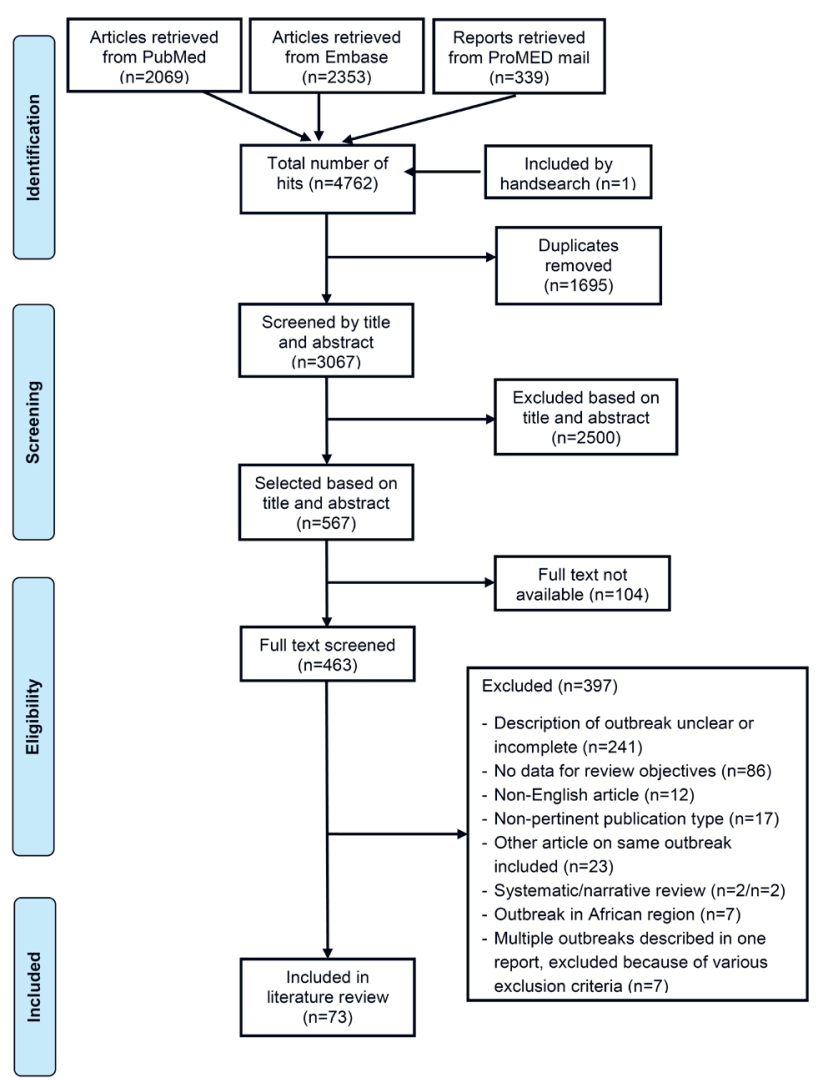

Figure 1. Summary of study selection process. tern of outbreaks by assessing the number of outbreaks that occurred each month split by Northern and Southern Hemisphere, and the occurrence of outbreaks in 10-year periods (1966-1975, 1976-1985, 1986-1995, 1996-2005, 2006-July 2017). Where possible, CFRs were calculated for each included outbreak as the number of deaths/number of cases.

\section{RESULTS}

After removal of duplicates from the 4762 publications identified from PubMed, EMBASE and ProMED mail, 3067 publications were screened and 73 were included in this review; 66 from the peer-reviewed literature, 7 from ProMED mail (Figure 1). Details of the included studies are included in Table S2 in Online Supplementary Document; the 73 included studies reported outbreak data from 83 meningococcal outbreaks (Table 1).

\section{Characteristics of the patients}

Age and gender were only reported for outbreaks of meningococcal disease identified in the peer-reviewed literature. There was a large variety of age ranges, and some studies only reported imprecise ranges (Table S2 in Online Supplementary Document). In $72 \%$ (26/36) of the outbreaks for which gender was reported, more than $50 \%$ of the cases in the outbreak were male (Table S2 in Online Supplementary Document). 
Table 1. Summary of outbreaks of meningococcal disease in non-African countries by region

\begin{tabular}{|c|c|c|c|c|}
\hline Country (hegion) & OUtBREAK PERIOD & $\begin{array}{l}\text { NUMBER } \\
\text { OF CASES }\end{array}$ & $\begin{array}{l}\text { Predominant } \\
\text { Serogroup }\end{array}$ & $\begin{array}{l}\text { CFR } \\
\text { (DEATHS/CASES) }\end{array}$ \\
\hline \multicolumn{5}{|l|}{ Region of the Americas } \\
\hline Canada (Eastern Ontario/Western Quebec) [19] & December 1991 - January 1992 & 10 & C & $50 \%(5 / 10)$ \\
\hline Canada (Kitchener-Waterloo, Ontario) [20] & 3 December 1997 - 4 January 1998 & 7 & C & $29 \%(2 / 7)$ \\
\hline Canada (Edmonton, Alberta) [21] & December 1999 - April 2001 & 61 & $\mathrm{C} \dagger$ & {$[4 \%(2 / 56)]$} \\
\hline Canada (Abbotsford, British Columbia) [22] & December 2000 - March 2001 & 5 & $\mathrm{C}$ & $40 \%(2 / 5)$ \\
\hline Canada (Toronto, Ontario) [23] & Early May - mid July 2001 & 6 & C & $33 \%(2 / 6)$ \\
\hline Canada (Abbotsford, British Columbia) [22] & October 2001 - December 2001 & 4 & C & $75 \%(3 / 4)$ \\
\hline Canada (Abbotsford, British Columbia) [22] & September - December 2004 & 7 & C & $71 \%(5 / 7)$ \\
\hline Canada (Nova Scotia) [24] & 1-11 February 2015 & 2 & B & $50 \%(1 / 2)$ \\
\hline $\begin{array}{l}\text { USA (United States Army Infantry Training Center, Fort Lewis, } \\
\text { Washington) [25] }\end{array}$ & 14 December 1970 - June 1971 & 15 & C & {$[100 \%(3 / 3)]$} \\
\hline USA (Los Angeles area, San Francisco area) [26] & 1-13 April 1974 & 5 & B & NR \\
\hline USA (Washington DC) [27] & 9-16 May 1979 & 3 & B & $0 \%(0 / 3)$ \\
\hline USA (Vermont) [28] & 15 February 1984 & 13 & $\mathrm{C}$ & $0 \%(0 / 13)$ \\
\hline USA (Rockbridge County, northwestern Virginia) [29] & 15-16 February 1986 & 5 & C & $0 \%(0 / 5)$ \\
\hline USA (Benton, Chelan, Douglas, Grant, Klickitat, and Yakima) [30] & 12 January - August 1989 & 28 & C & NR $\ddagger$ \\
\hline USA (Santa Clara County, California) [31] & 27 January - 7 February 1989 & 5 & C & $0 \%(0 / 5)$ \\
\hline USA (Benton, Chelan, Douglas, Grant, Klickitat, and Yakima) [30] & September 1989 - August 1990 & 12 & C & $\mathrm{NR} \ddagger$ \\
\hline USA (Benton, Chelan, Douglas, Grant, Klickitat, and Yakima) [30] & September 1990 - August 1991 & 5 & C & NR申 \\
\hline USA (region NR) [32] & 8 February 1991 - 0 April 1992 & 9 & C & $33 \%(3 / 9)$ \\
\hline USA (Iowa City, Iowa) [33] & 23 October - 15 December 1992 & 5 & C & $0 \%(0 / 5)$ \\
\hline USA (Los Angeles County Men's Jail system, California) [34] & 1 January - 31 March 1993 & 11 & $\mathrm{C} \S$ & NR \\
\hline USA (Grayson County, North Texas) [35] & 24 February - 21 March 1993 & 7 & C & $14 \%(1 / 7)$ \\
\hline USA (Connecticut) [36] & May 1993 & 3 & A & $0 \%(0 / 3)$ \\
\hline USA (region NR) [37] & 11-18 February 1995 & 6 & B & $0 \%(0 / 6)$ \\
\hline USA (Florida) [38] & 8 July - August 1995 & 5 & $\mathrm{~B}$ & $20 \%(1 / 5)$ \\
\hline USA (Florida) [38] & 2-10 December 1997 & 3 & $\mathrm{~B}$ & $33 \%(1 / 3)$ \\
\hline USA (Putnam County, Florida) [39] & 12 December 1998 - 28 December 1999 & 12 & C & $17 \%(2 / 12)$ \\
\hline USA (Chicago) [40] & 6-15 October 2003 & 6 & C & $50 \%(3 / 6)$ \\
\hline USA (central Brooklyn, New York) [41] & 1 November 2005 - 30 November 2006 & 23 & C & $30 \%(7 / 23)$ \\
\hline USA (northeastern Oklahoma) [42] & 10 March-31 March 2010 & 7 & C\# & {$[40 \%(2 / 5)]$} \\
\hline USA (California) [43] & March-November 2013 & 5 & $\mathrm{~B}$ & NR \\
\hline USA (New Jersey) [44] & 25 March 2013 - 10 March 2014 & 9 & B & $11 \%(1 / 9)$ \\
\hline USA (Eugene, Oregon) $[45,46]$ & 13 January - 19 May 2015 & 7 & B & $14 \%(1 / 7)$ \\
\hline USA (Providence College, Rhode Island) [47] & 2-5 February 2015 & 2 & B & $0 \%(0 / 2)$ \\
\hline USA (Santa Clara University, California) [48] & 31 January - 2 February 2016 & 3 & B & $0 \%(0 / 3)$ \\
\hline Brazil (Rio Verde city) [49] & June-August 2008 & 22 & C\# & {$[31 \%(5 / 16)]$} \\
\hline Brazil (Trancoso, Seguro, Bahia State) [50] & 21-26 October 2009 & 9 & C & $67 \%(6 / 9)$ \\
\hline Brazil (Cosmópolis and Sa“o José dos Campos, Sa`o Paulo State) [51] & 29 March - 30 June 2010 & 18 & C & $17 \%(3 / 18)$ \\
\hline Brazil (Cosmópolis and Săo José dos Campos, Săo Paulo State) [51] & 10 July -8 August 2010 & 13 & $\mathrm{C}$ & $46 \%(6 / 13)$ \\
\hline Chile (Metropolitan Region, includes Santiago) [52] & January - November 2013 & 46 & W135 & NR \\
\hline Mexico (Tijuana) [53] & 30 January - 30 March 2013 & 19 & C & $37 \%(7 / 19)$ \\
\hline Trinidad and Tobago (El Socorroi, San Juan and Claxton Bay) [54] & 26 September - 10 October 1998 & 21 & BII & [57\% (8/14)] \\
\hline \multicolumn{5}{|l|}{ European region } \\
\hline Belgium, Denmark, Germany, The Netherlands (region NR) [55] & 9 May - 24 December 1997 & 11 & C & $9 \%(1 / 11)$ \\
\hline Czech Republic (Olomouc and Bruntal) [56] & 2 February - 8 May 1993 & 8 & C & NR \\
\hline Czech Republic (Olomouc and Bruntal) [56] & 14 February - 2 June 1993 & 6 & C & NR \\
\hline Denmark (Randers) [57] & November 1983 - May 1984 & 20 & C & $5 \%(1 / 20)$ \\
\hline $\begin{array}{l}\text { Denmark (Hillerød municipality, Karlebo: Hørsholm and Hillerød, } \\
\text { Frederiksborg county) [58] }\end{array}$ & January - April 1987 & 6 & B & NR \\
\hline $\begin{array}{l}\text { Denmark (Hillerød municipality, Karlebo: Hørsholm and Hillerød, } \\
\text { Frederiksborg county) [58] }\end{array}$ & August - December 1987 & 6 & B & NR \\
\hline $\begin{array}{l}\text { Denmark (Hillerød municipality, Karlebo: Hørsholm and Hillerød, } \\
\text { Frederiksborg county) [58] }\end{array}$ & 1988 & 8 & $\mathrm{~B}^{* *}$ & NR \\
\hline
\end{tabular}


Table 1. Continued

\begin{tabular}{|c|c|c|c|c|}
\hline Country (Region) & OUTBREAK PERIOD & $\begin{array}{l}\text { NUMBER } \\
\text { OF CASES }\end{array}$ & $\begin{array}{l}\text { Predominant } \\
\text { SERogroup }\end{array}$ & $\begin{array}{c}\text { CFR } \\
\text { (DEATHS/CASES)* }\end{array}$ \\
\hline $\begin{array}{l}\text { Denmark (Hillerød municipality, Karlebo: Hørsholm and Hillerød, } \\
\text { Frederiksborg county) [58] }\end{array}$ & January - March 1989 & 6 & B & NR \\
\hline France (Indre-et-Loire) [59] & November 2000 - February 2002 & 8 & B & $13 \%(1 / 8)$ \\
\hline France (Dax, Landes) [60] & December 2008 - September 2009 & 11 & $\mathrm{~B}$ & $9 \%(1 / 11)$ \\
\hline France (Pays de la Loire and Rhone-Alpes) [61] & 12 February - 1 April 2012 & 16 & W135 & {$[0 \%(0 / 8)]$} \\
\hline Germany (Rottal-Inn County) [62] & 10 December 1997 - 2 March 1998 & 9 & C & $11 \%(1 / 9)$ \\
\hline Germany (Berlin) [63] & October 2012 - May 2013 & 5 & $\mathrm{C}$ & $80 \%(4 / 5)$ \\
\hline $\begin{array}{l}\text { Greece (Hellenic Air Force recruit center and training base, } \\
\text { southern Greece) [64] }\end{array}$ & 19-24 January 1996 & 10 & $\mathrm{C}$ & $0 \%(0 / 10)$ \\
\hline Italy (Treviso area, Veneto region, northeastern Italy) [65] & 13 December 2007 - 4 January 2008 & 9 & $\mathrm{C}$ & {$[43 \%(3 / 7)]$} \\
\hline Italy (region NR) [66] & October 2012 & 4 & C & $0 \%(0 / 4)$ \\
\hline $\begin{array}{l}\text { The Netherlands (Zevenbergen, Klundert, Standdaarbuiten, } \\
\text { Etten-Leur) [67] }\end{array}$ & 26 July - 1 August 2001 & 7 & $\mathrm{C}$ & NR \\
\hline Norway (Tromsø, Northern-Norway) [68] & September - November 1981 & 3 & $\mathrm{~B}$ & $67 \%(2 / 3)$ \\
\hline Norway (northern Norway) [69] & 1983 & 3 & $\mathrm{~B}$ & $33 \%(1 / 3)$ \\
\hline Poland (Skwierzyna, Lubuskie, a western province of Poland) [70] & 22-24 March 2006 & 4 & $\mathrm{C}$ & $0 \%(0 / 4)$ \\
\hline $\begin{array}{l}\text { Poland (Goleniów and Załom in commune Goleniów and Łoźnica } \\
\text { in commune Przybiernów, Goleniów County) [71] }\end{array}$ & 10-30 March 2009 & 6 & $\mathrm{C}$ & $0 \%(0 / 6)$ \\
\hline Spain (Logrofio, Rioja) [72] & 13 November 1981 - 22 February 1982 & 11 & $\mathrm{C}$ & $18 \%(2 / 11)$ \\
\hline Spain (Lloret de Mar, Catalonia, northeast Spain) [73] & 29 January - 2 May 1996 & 5 & B & $40 \%(2 / 5)$ \\
\hline Sweden/Scotland (across Sweden/north of Scotland) [74] & 12-17 August 2015 & 13 & W135 & $0 \%(0 / 13)$ \\
\hline UK (Devon) [75] & October 1972 - May 1973 & 31 & $\mathrm{~B}$ & $19 \%(6 / 31)$ \\
\hline UK (region NR) [76] & 16 October - 2 December 1996 & 7 & $\mathrm{C} \dagger \dagger$ & $29 \%(2 / 7)$ \\
\hline UK (Rotherham and North Nottinghamshire health districts) [77] & 8 December 1995 - 16 January 1996 & 8 & $\mathrm{C}$ & $13 \%(1 / 8)$ \\
\hline UK (University of Southampton) [78] & October 1997 & 6 & C & $50 \%(3 / 6)$ \\
\hline UK (West Midlands, England) [79] & 23 August - 23 September 2010 & 2 & $\mathrm{~B}$ & {$[0 \%(0 / 1)]$} \\
\hline UK (Warwickshire area) [80] & February - June 2013 & 5 & $\mathrm{~B}$ & {$[0 \%(0 / 3)]$} \\
\hline \multicolumn{5}{|l|}{ South-East Asian region } \\
\hline India (Delhi) [81,82] & April - July 2005 & 444 & $\mathrm{C}$ & $14 \%(62 / 444)$ \\
\hline India (Delhi) [83] & December 2005 - June 2006 & 531 & $\mathrm{~A} \neq$ & [6\% (15/257)] \\
\hline India (Kashmir) [84] & 1 February - 26 May 2006 & 17 & A & $12 \%(2 / 17)$ \\
\hline \multicolumn{5}{|l|}{ Eastern Mediterranean region } \\
\hline Israel (Israel Defense Force, not further specified) [85] & 18-23 January 1992 & 3 & $\mathrm{C}$ & NR \\
\hline Israel (Israel Defense Force, not further specified) [85] & 23-24 January 1992 & 2 & C & NR \\
\hline Israel (Israel Defense Force, not further specified) [85] & 6-20 February 1993 & 3 & C & NR \\
\hline Saudi-Arabia (Makkah) [86] & 19 March - 15 June 1992 & 182 & A§§ & {$[15 \%(15 / 102)]$} \\
\hline \multicolumn{5}{|l|}{ Western Pacific region } \\
\hline Australia (Doomadgee, northern Queensland) [87] & 24 September 1990 - 11 April 1991 & 11 & $\mathrm{C}$ & $9 \%(1 / 11)$ \\
\hline Australia (western Sydney, Penrith local government area) [88] & 1 August - 10 September 1996 & 14 & $\mathrm{C}$ & $0 \%(0 / 14)$ \\
\hline China (Jinan City) [89] & May 2010 & 3 & $\mathrm{C}$ & NR \\
\hline New-Zealand (Northland) [90] & 10 July - 21 December 2011 & 13 & C\#\# & {$[33 \%(3 / 9)]$} \\
\hline Taiwan (northern Taiwan) [91] & 3-24 July 2017 & 3 & NR & $33 \%(1 / 3)$ \\
\hline
\end{tabular}

CFR - case-fatality rate, NR - not reported

* Fatal outcome not reported for all outbreak cases. CFR calculated for cases with known outcomes, indicated by square brackets.

$\$ 56 / 57$ serogrouped isolates were serogroup C; $1 / 57$ serogrouped isolates were serogroup B. CFR calculated for 56 cases with serogroup C.

$¥$ Houck et al. reported the total number of deaths for three outbreaks combined: 9 cases died.

$\S 8 / 11$ serogrouped isolates were serogroup C; $1 / 11$ serogrouped isolates were serogroup B.

\#Mortality reported for laboratory and clinically confirmed cases, but not for suspected cases.

T113/14 serogrouped isolates were serogroup B; 1/14 serogrouped isolates were serogroup A. CFR calculated for 14 confirmed cases (serogroup B and A).

$* * 7 / 8$ serogrouped isolates were serogroup B; $1 / 8$ serogrouped isolates were serogroup C.

$\uparrow \uparrow 4 / 5$ serogrouped isolates were serogroup C; 1/5 serogrouped isolates was serogroup B.

$\$ \$ 42 / 195$ serogrouped isolates were serogroup A; 65/195 serogrouped isolates had agglutination with combined ACYW135 antigen. CFR calculated for 257 confirmed cases.

$\S \S$ Mortality reported for confirmed cases.

\#\#9/13 serogrouped isolates were serogroup C; 4/13 serogrouped isolates were serogroup B. 


\section{Characteristics of the outbreaks}

The majority of outbreaks were identified in the regions of the Americas (41/83 outbreaks; US, 29/83; Canada, 8/83; Central and South America, 7/83), followed by the European region (30/83 outbreaks). In each of the Western Pacific, Eastern Mediterranean, and South-East Asian regions there were $<10$ outbreaks identified (Figure 2 and Table 1). In the included outbreaks the number of cases ranged from 2 to 531 , with $34 \%$ of outbreaks including $>10$ cases (Table 1); the outbreaks with the largest number of cases were seen in the South-East Asian region (Figure 2). Of the 54 outbreaks where CFR was calculated for all reported outbreak cases, it ranged from 0 to $80 \%$ (Table 2); the breakdown of CFRs by region is presented in Table S3 in Online Supplementary Document, however due to the small numbers of cases and the large ranges, these data should be interpreted with caution.

The most frequently reported outbreak settings were regions (such as [health] districts, areas, counties, departments, provinces; $\mathrm{n}=20)$ and towns/villages/cities $(\mathrm{n}=16) ; 15$ outbreaks occurred in a school setting (11 of which were at universities), and other common settings included military bases ( $n=9)$, nursery settings $(n=4)$, working environments $(n=3)$ and communities $(n=3)$ (Table S2 in Online Supplementary Document).

Serogroup C was the predominant serogroup in $61 \%$ of the outbreaks, followed by serogroup B (29\%), serogroup A (5\%) and serogroup W135 (4\%); for one outbreak the serogroup was not reported. The timing and duration of outbreaks are visualized in Figure S1 in Online Supplementary Document. In the regions of the Americas between 1989 and 1993, there were multiple serogroup C outbreaks with several months duration, and a cluster of serogroup B outbreaks were reported between 2012 and 2016. In the

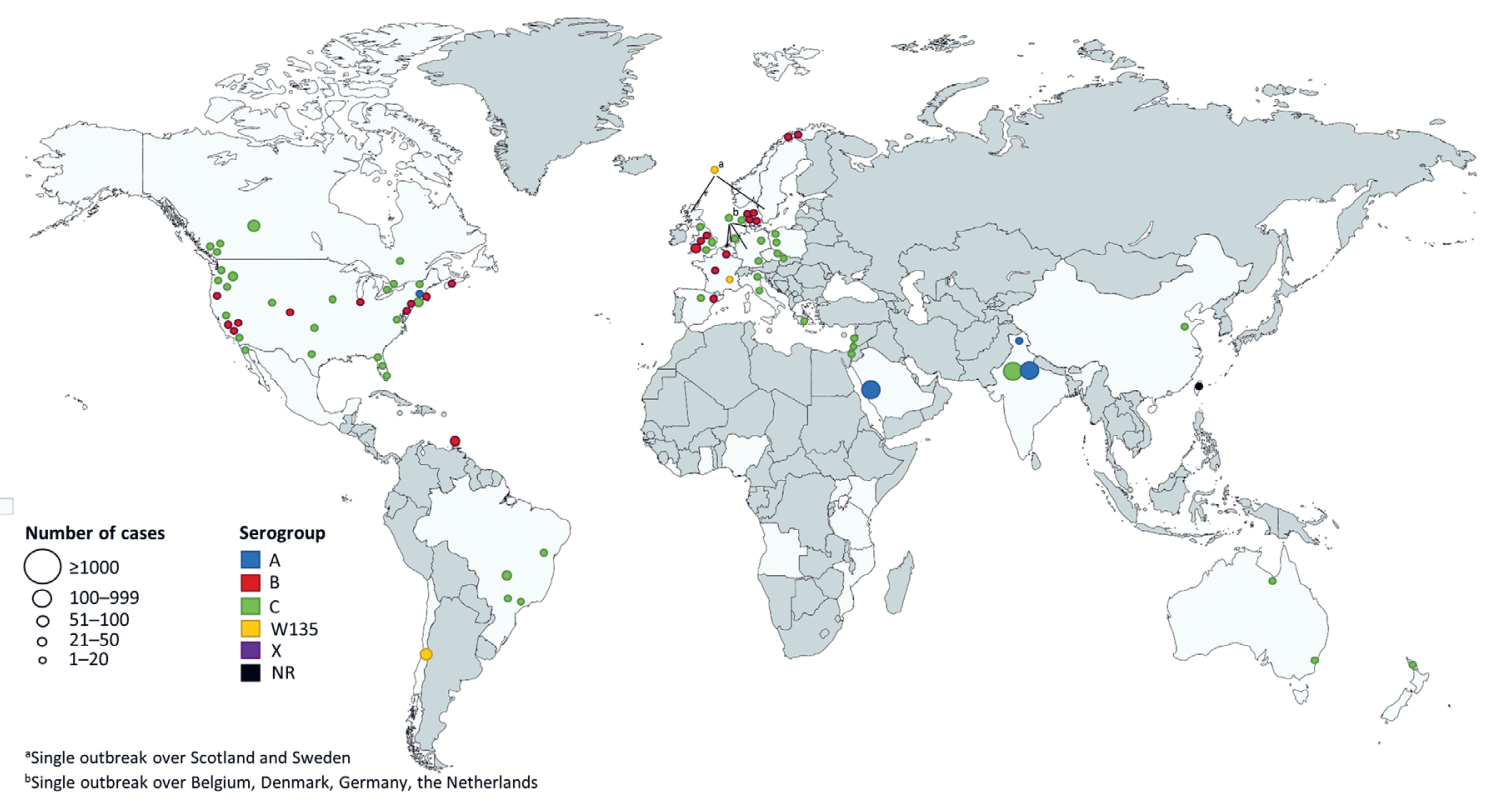

Figure 2. View of reported meningococcal outbreaks in non-African countries over the last 50 years.

Table 2. CFR range of outbreaks of meningococcal disease in non-African countries

\begin{tabular}{lcccc} 
& \multicolumn{2}{c}{ CFR (\%) RANGE } & Total \\
Serogroup A & Children & Adults & Children and adults & $0.0 \%-14.7 \%$ \\
\hline Serogroup B & NA & $0.0 \%-11.8 \%$ & $5.8 \%-14.7 \%$ & $0.0 \%-40.0 \%$ \\
\hline Serogroup C & $0.0 \%-40.0 \%$ & $0.0 \%-33.3 \%$ & $0.0 \%-19.4 \%$ & $0.0 \%-80.0 \%$ \\
\hline Serogroup W135 & $0.0 \%-50.0 \%$ & $0.0 \%-80.0 \%$ & $0.0 \%-66.7 \%$ & $0.0 \%$ \\
\hline All serogroups & NA & NA & $0.0 \%$ & $0.0 \%-80.0 \%$ \\
\hline
\end{tabular}

CFR - case-fatality rate, NA - not applicable 
European region, multiple serogroup B outbreaks with varying duration occurred over the last 50 years, and outbreaks of serogroup $C$ were of short duration. Two serogroup C outbreaks in the Western Pacific region lasted for several months, while other outbreaks were of shorter duration. In the Eastern Mediterranean region all reported outbreaks, which occurred between 1992 and 1994, were of short duration and with serogroup $C$ as the predominant serogroup. All identified outbreaks in the South-East Asian region were predominantly serogroup A and occurred after 2005.

When the occurrence of meningococcal outbreaks was examined by 10-year period, for each region it was seen that serogroup C outbreaks have been the most dominant, particularly since 1986 (Figure 3). Outbreaks due to serogroup B were identified in the region of the Americas and Europe over each of the 10-year periods (Figure 3). Low numbers of serogroup A outbreaks were reported over each period, and serogroup W135 outbreaks were only identified in the last 10 years in the region of the Americas and the European region (Figure 3).

The seasonal pattern for the month of onset of meningococcal outbreaks showed a peak in the colder months of October, December, January and February in the Northern Hemisphere, and between June and October in the Southern Hemisphere (Figure 4).

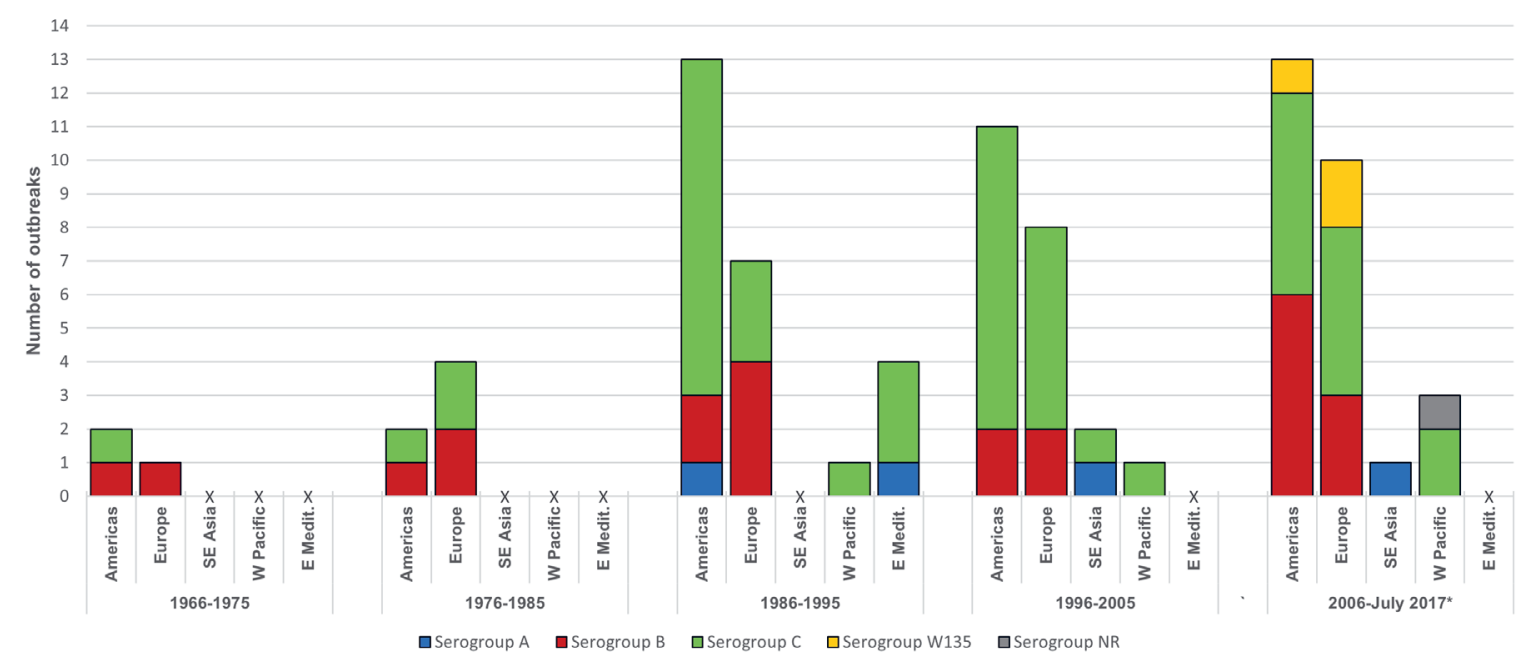

Figure 3. Number of outbreaks per region per 10-year period (1966-July 2017). Americas - Region of the Americas; E Medit. - Eastern Mediterranean region; Europe - European region; SE. Asia - South-East Asian region; W Pacific - Western Pacific region; X - no cases; NR - not reported. *Outbreaks in the last 1.5 years (2016-July 2017) were added to the period 2006-2015. Outbreaks which covered two 10-year periods (ie, from December 2005 to June 2006) were included in the 10-year period in which the outbreak started $(n=3)$.

\section{DISCUSSION}

In this systematic review of meningococcal outbreaks reported over the last 50 years we show that a substantial proportion of the outbreaks identified were due to serogroup C, particularly in the regions of the Americas and Europe. Serogroup B was consistently reported in the regions of the Americas and in Europe over the last 50 years, but there appears to have been a recent increase in the number of outbreaks in the Americas region. We also identify the emergence of documented outbreaks due to serogroup W135 in recent years in South America and Europe.

Meningococcal disease patterns have been documented to vary widely over time and between geographical areas, while some of these patterns are similar to those we observed for outbreaks in this review, there are some variations. Historically, serogroup A was responsible for large epidemics across Europe, but there has been a more recent shift to the predominance of serogroup B (currently responsible for $\sim 80 \%$ of cases), and for the emergence of serogroups Y and W135 [1,3,6,92]. The findings of this review differ from the pattern of epidemics, in that the predominate serogroups responsible for meningococcal disease out- 
A.

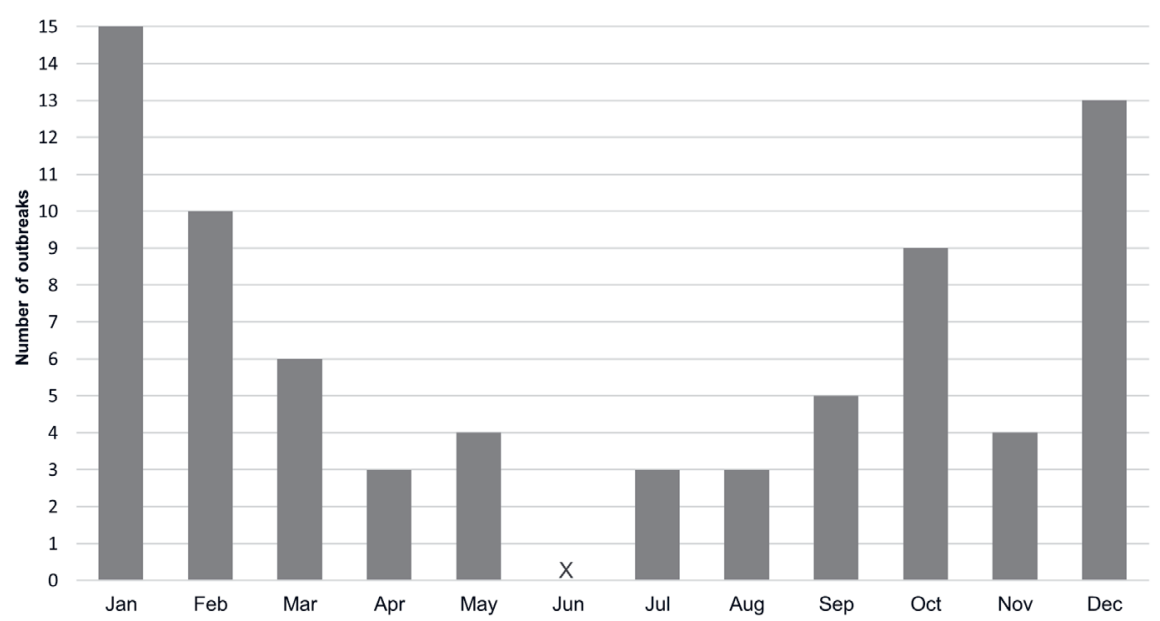

B.

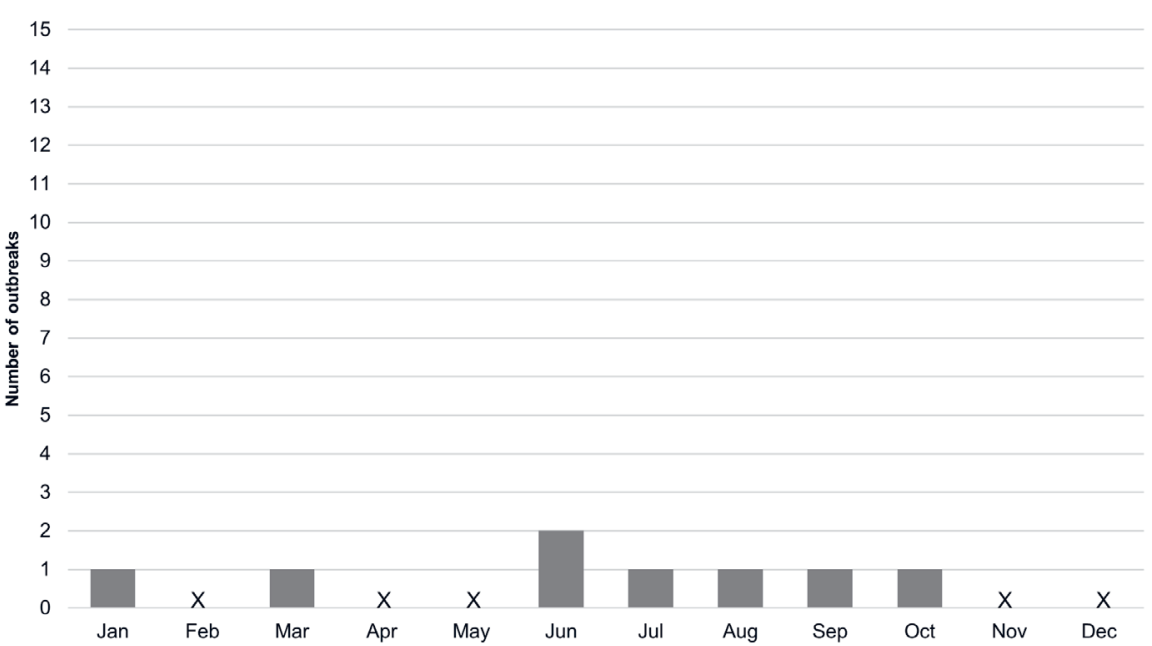

Figure 4. Outbreaks by month of onset in the (A) Northern Hemisphere and (B) Southern Hemisphere. X - no cases.

breaks in Europe over the last 50 years was serogroup C, and to a lesser extent serogroup B. In the USA the incidence of meningococcal disease is low and, until recently, serogroup $C$ was responsible for the majority of cases, with serogroup B at a consistent level (30\%-40\% of all disease); cases related to serogroup Y have been recently identified $[1,6,7]$. A similar pattern was seen in this review for outbreaks over the region of the Americas. The pattern of meningococcal disease in South America is very diverse with wide variation across countries $[1,6,92]$. In Asia, a shift has also been seen from a prevalence of serogroup A to serogroups B and C [1]. Many cases of meningococcal disease reported in the Eastern Mediterranean region are associated with the Hajj pilgrimage, and most recently these were due to the W135 serogroup [3]. For the South-East Asia and Eastern Mediterranean regions, the numbers of outbreaks identified in this review are too small to describe patterns of disease.

Following the introduction of vaccination, in particular with the use of conjugated vaccines in routine vaccination programs, studies of meningococcal epidemics have illustrated changes in the patterns of meningococcal disease. In Europe, serogroup B has become the dominant serogroup following widespread use of MenC vaccine from 1999 [1,6,92]. The introduction of MenB outer membrane vesicle vaccines in Cuba, Norway and New Zealand has shown to reduce the incidence of meningococcal disease caused 
by serogroup B [93], and the recent utilization of the new serogroup B vaccines (four-component MenB vaccine (MenB-4C) and MenB-FHbp) may act to curb outbreaks in the USA $[44,94]$. In Africa the introduction of the MenAfriVac MenA conjugate vaccine has radically reduced the incidence of disease caused by serogroup A, the main causative agent in the meningitis belt $[95,96]$, This evidence demonstrates that vaccination provides a valuable resource for reducing epidemics caused by dominant vaccine serogroups and for limiting outbreaks. However, vaccination may also change the pattern of meningococcal outbreaks and epidemics, from these dominant serogroup to other serogroups, highlighting the importance of surveillance for monitoring trends in disease.

The outbreaks captured in this systematic review show a pattern of seasonality, with peaks during the winter months in both the Northern and Southern Hemispheres. This seasonality of meningococcal disease has previously been shown in the African meningitis belt, where peaks in epidemic disease occur when the humidity is at its lowest and then fall with the increase in humidity and the start of the rainy season [97]. A possible explanation is that the low humidity and dry winds damage mucosal barriers, facilitating transmission [97]. A study of the seasonal dynamics of confirmed bacterial meningitis has also shown a worldwide pattern of seasonality to infection [98].

The age groups previously identified to be at highest risk for meningococcal disease are infants, and adolescents or young adults [1,3,6]; with additional epidemiological evidence suggesting that regionally some serogroups are more common in certain age groups such as serogroup B in infants and Y in elderly populations in the USA $[1,6]$. Unfortunately, due to the inconsistent reporting of age in the identified publications in this review, it was not possible to draw any meaningful conclusions on the ages of those in these outbreaks. There is some conflicting evidence to suggest that male gender is a risk factor for meningococcal disease [99-101]. In this review, there was a higher proportion of males with meningococcal disease than females in the majority of included outbreaks; however, it must be taken into consideration that some settings may not have had an equal balance in gender, such as military settings, and this may have influenced these results.

One limitation to studies such as these is the limited surveillance protocols and testing facilities in some regions over time. In some countries the reporting of meningitis is not mandatory, or there is no surveillance network in place [102], consequently outbreaks of meningitis may not be documented. Some countries may also not have the facilities to accurately serogroup cases of meningococcal disease, or this may have been introduced relatively recently [102-105], consequently affecting the incidence patterns that we see here. Continuing surveillance and increasing access to testing facilities serotyping methods will further help to understand the trends in meningococcal outbreaks, as well as help identify outbreaks as they occur and take necessary action.

This systematic review identified documented meningococcal disease outbreaks reported over a 50-year period, and included a large amount of data. This allowed the examination of the temporal variation of meningococcal disease, how serogroup prevalence changed over time, and also provides a benchmark to monitor future changes in outbreaks. There are several limitations to this study, first, this review only captures outbreaks that were published in peer-reviewed publications or in the grey literature, and so the number and extent of meningococcal outbreaks will have been underestimated. There were few reports of outbreaks from the Eastern Mediterranean, Western Pacific and South-East Asia regions, which limits the generalizability of these findings. Many reports from the grey literature had no clear end date and so were excluded and a number of the articles identified could not be retrieved in full text. However, most of these articles were published in low-impact journals or concerned non-English articles. In the literature the term 'outbreak' was often used interchangeably with 'epidemic'; only studies reporting on outbreaks following the definition of the CDC (same serogroup affecting a population during a shorter time period) were included. There were variations in case definitions and methods for confirmation and diagnosis for meningococcal disease, which made comparison between studies difficult. Also, the total number of deaths following the outbreak was not always reported and so CFRs were calculated based on the number of cases where the outcome was known, which may have resulted in an under- or overestimation of the true CFR. Finally, most studies included in this review concerned outbreak notifications or vaccination studies, with a limited description of the outbreak and the outbreak cases were often not studied extensively enough to draw conclusions on at-risk groups or risk factors.

This systematic review provides an overview of meningococcal disease outbreaks in several geographical areas over the last 50 years, which highlights the predominance of serogroup $C$ and the recent emergence of W135 as the causative serogroup. The data presented here can be valuable for use in public health strategies, and monitoring future changes in outbreaks. 


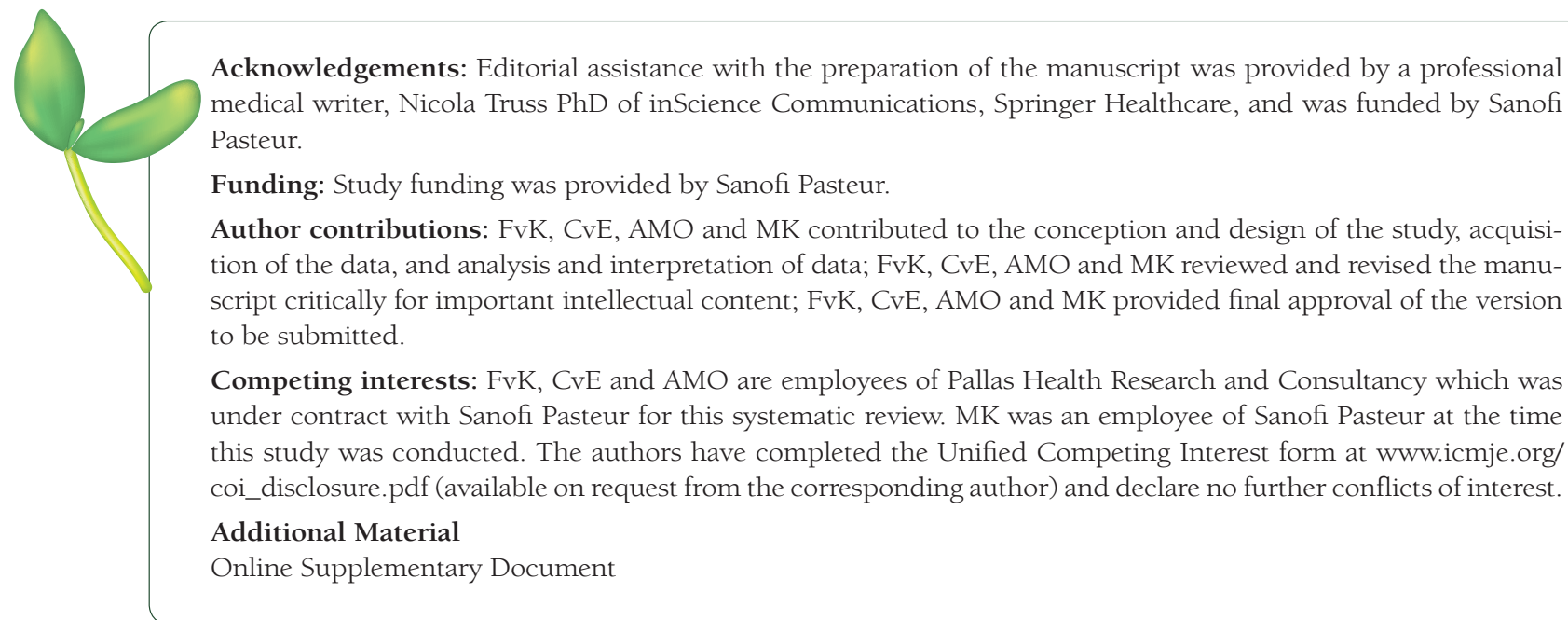

1 Rouphael NG, Stephens DS. Neisseria meningitidis: biology, microbiology, and epidemiology. Methods Mol Biol. 2012;799:1-20. Medline:21993636 doi:10.1007/978-1-61779-346-2_1

2 van Deuren M, Brandtzaeg P, van der Meer JWM. Update on Meningococcal Disease with Emphasis on Pathogenesis and Clinical Management. Clin Microbiol Rev. 2000;13:144-66. Medline:10627495 doi:10.1128/CMR.13.1.144

3 Jafri RZ, Ali A, Messonnier NE, Tevi-Benissan C, Durrheim D, Eskola J, et al. Global epidemiology of invasive meningococcal disease. Popul Health Metr. 2013;11:17. Medline:24016339 doi:10.1186/1478-7954-11-17

4 World Health Organization. Meningococcal meningitis. Fact sheet. Available: http://www.who.int/mediacentre/factsheets/fs141/en/\#. Accessed: 14 December 2017.

5 Organization WH. Meningococcal vaccines: WHO position paper, November 2011. Wkly Epidemiol Rec. 2011;86:52139. Medline:22128384

6 Pelton SI. The Global Evolution of Meningococcal Epidemiology Following the Introduction of Meningococcal Vaccines. J Adolesc Health. 2016;59:S3-11. Medline:27449148 doi:10.1016/j.jadohealth.2016.04.012

7 Chang Q, Tzeng YL, Stephens DS. Meningococcal disease: changes in epidemiology and prevention. Clin Epidemiol. 2012;4:237-45. Medline:23071402

8 Kuhdari P, Stefanati A, Lupi S, Valente N, Gabutti G. Meningococcal B vaccination: real-world experience and future perspectives. Pathog Glob Health. 2016;110:148-56. Medline:27309042 doi:10.1080/20477724.2016.1195072

9 Public Health England. Meningococcal B (MenB) vaccination programme. Available: https://www.gov.uk/government/ collections/meningococcal-b-menb-vaccination-programme. Accessed: 5 January 2018.

10 Patton ME, Stephens D, Moore K, MacNeil JR. Updated recommendations for use of MenB-FHbp Serogroup B Meningococcal Vaccine - Advisory Committee on Immunization Practices, 2016. MMWR Morb Mortal Wkly Rep. 2017;66:509-13. Medline:28520709 doi:10.15585/mmwr.mm6619a6

11 Centers for Disease Control and Prevention. Meningococcal Outbreaks. Available: https://www.cdc.gov/meningococcal/ outbreaks/index.html. Accessed: 14 December 2017.

12 European Centre for Disease Prevention and Control. Meningococcal disease: recommended vaccinations. Available: https://vaccine-schedule.ecdc.europa.eu/Scheduler/ByDisease?SelectedDiseaseId=48\&SelectedCountryIdByDisease=-1. Accessed: 14 December 2017.

13 Davis KL, Misurski D, Miller J, Karve S. Cost impact of complications in meningococcal disease: Evidence from a United States managed care population. Hum Vaccin. 2011;7:458-65. Medline:21795848 doi:10.4161/hv.7.4.14434

14 Wang B, Haji Ali Afzali H, Marshall H. The inpatient costs and hospital service use associated with invasive meningococcal disease in South Australian children. Vaccine. 2014;32:4791-8. Medline:24998605 doi:10.1016/j.vaccine.2014.05.069

15 Darbŕ J, Kaskens L, Hark M, Wright C. Costs of surviving meningococcal disease in Spain: Evaluation for two cases of severe meningitis and septicaemia. Vaccine. 2014;32:5006-12. Medline:25045813 doi:10.1016/j.vaccine.2014.07.019

16 Bénard S, Wright C, Voisine J, Olivier CW, Gaudelus J. Lifetime cost of meningococcal disease in France: Scenarios of severe meningitis and septicemia with purpura fulminans. J Infect Public Health. 2016;9:339-47. Medline:26688376 doi:10.1016/j.jiph.2015.10.016

17 Wright C, Wordsworth R, Glennie L. Counting the Cost of Meningococcal Disease. Paediatr Drugs. 2013;15:49-58. Medline:23322553 doi:10.1007/s40272-012-0006-0

18 Oordt A, Kyaw M. Ende CVd, Kessel FV. Meningococcal outbreaks. Available: http://www.crd.york.ac.uk/PROSPERO/ display_record.php?ID=CRD42017074957. Accessed: 14 December 2017.

19 Banerji A, King WJ, MacDonald N, Li M. Use of single dose ceftriaxone in the emergency department during an outbreak of serogroup C meningococcal disease. Pediatr Infect Dis J. 1995;14:904-5. Medline:8584321 doi:10.1097/00006454199510000-00017 
20 Gold R. Meningitis, meningococcal - USA (Rhode Island) (06) ProMED mail. Archive Number: 19980306.0423.

21 Tyrrell GJ, Chui L, Johnson M, Chang N, Rennie RP, Talbot JA. Outbreak of Neisseria meningitidis, Edmonton, Alberta, Canada. Emerg Infect Dis. 2002;8:519-21. Medline:11996690 doi:10.3201/eid0805.010337

22 Quan G, Gilbert M, David ST, Rahim T, Adie K, Shaw C, et al. Usefulness of pulsed-field gel electrophoresis in tracking two outbreaks of invasive meningococcal disease serogroup C in British Columbia. Can J Infect Dis Med Microbiol. 2007;18:363-7. Medline:18978987 doi:10.1155/2007/295973

23 Tsang RS, Kiefer L, Law DK, Stoltz J, Shahin R, Brown S, et al. Outbreak of serogroup C meningococcal disease caused by a variant of Neisseria meningitidis serotype 2a ET-15 in a community of men who have sex with men. J Clin Microbiol. 2003;41:4411-4. Medline:12958279 doi:10.1128/JCM.41.9.4411-4414.2003

24 Langley JM, MacDougall DM, Halperin BA, Swain A, Halperin SA, Top KA, et al. Rapid surveillance for health events following a mass meningococcal B vaccine program in a university setting: A Canadian Immunization Research Network study. Vaccine. 2016;34:4046-9. Medline:27302338 doi:10.1016/j.vaccine.2016.06.025

25 Guttler RB, Beaty HN. Minocycline in the chemoprophylaxis of meningococcal disease. Antimicrob Agents Chemother. 1972;1:397-402. Medline:4670480 doi:10.1128/AAC.1.5.397

26 Oill PA, Chow AW, Roberto RR, Guze LB. An intercity outbreak of meningococcal meningitis in adults. West J Med. 1978;128:189-94. Medline:636407

27 Brook I, Gorman R, Johnson MW. Outbreak of meningococcal disease in a family. South Med J. 1980;73:902-3. Medline:7384853 doi:10.1097/00007611-198007000-00021

28 Hudson PJ, Vogt RL, Heun EM, Brondum J, Coffin RR, Plikaytis BD, et al. Evidence for school transmission of Neisseria meningitidis during a Vermont outbreak. Pediatr Infect Dis. 1986;5:213-7. Medline:3081880 doi:10.1097/00006454198603000-00011

29 Harrison LH, Armstrong CW, Jenkins SR, Harmon MW, Ajello GW, Miller GB Jr, et al. A cluster of meningococcal disease on a school bus following epidemic influenza. Arch Intern Med. 1991;151:1005-9. Medline:2025124 doi:10.1001/ archinte.1991.00400050141028

30 Houck P, Patnode M, Atwood R, Powell K. Epidemiologic characteristics of an outbreak of serogroup C meningococcal disease and the public health response. Public Health Rep. 1995;110:343-9. Medline:7610228

31 Morrow HW, Slaten DD, Reingold AL, Werner SB, Fenstersheib MD. Risk factors associated with a school-related outbreak of serogroup C meningococcal disease. Pediatr Infect Dis J. 1990;9:394-8. Medline:2114607 doi:10.1097/00006454199006000-00005

32 Imrey PB, Jackson LA, Ludwinski PH, England AC III, Fella GA, Fox BC, et al. Outbreak of serogroup C meningococcal disease associated with campus bar patronage. Am J Epidemiol. 1996;143:624-30. Medline:8610679 doi:10.1093/ oxfordjournals.aje.a008792

33 Edmond MB, Hollis RJ, Houston AK, Wenzel RP. Molecular epidemiology of an outbreak of meningococcal disease in a university community. J Clin Microbiol. 1995;33:2209-11. Medline:7559983

34 Tappero JW, Reporter R, Wenger JD, Ward BA, Reeves MW, Missbach TS, et al. Meningococcal disease in Los Angeles County, California, and among men in the county jails. N Engl J Med. 1996;335:833-40. Medline:8778600 doi:10.1056/ NEJM199609193351201

35 Wenger JD, Jackson LA, Raj P, Tonelli MJ. Issues in the control of outbreaks of group C meningococcal disease in the United States. Infect Dis Clin Pract. 1994;3:136-40. doi:10.1097/00019048-199403000-00022

36 Dardick K, Riggs, J. Meningitis, meningococcal - USA (Rhode Island) (02) ProMED mail. Archive Number: 19980302.0405.

37 Jackson LA, Alexander ER, DeBolt CA, Swenson PD, Boase J, McDowell MG, et al. Evaluation of the use of mass chemoprophylaxis during a school outbreak of enzyme type 5 serogroup B meningococcal disease. Pediatr Infect Dis J. 1996;15:992-8. Medline:8933547 doi:10.1097/00006454-199611000-00012

38 Outbreaks of group B meningococcal disease-Florida, 1995 and 1997. MMWR Morb Mortal Wkly Rep. 1998;47:8337. Medline:9780239

39 Krause G, Blackmore C, Wiersma S, Lesneski C, Gauch L, Hopkins RS. Mass vaccination campaign following community outbreak of meningococcal disease. Emerg Infect Dis. 2002;8:1398-403. Medline:12498654 doi:10.3201/ eid0812.040421

40 Schmink S, Watson JT, Coulson GB, Jones RC, Diaz PS, Mayer LW, et al. Molecular epidemiology of Neisseria meningitidis isolates from an outbreak of meningococcal disease among men who have sex with men, Chicago, Illinois, 2003. J Clin Microbiol. 2007;45:3768-70. Medline:17728467 doi:10.1128/JCM.01190-07

41 Weiss D, Stern EJ, Zimmerman C, Bregman B, Yeung A, Das D, et al. Epidemiologic investigation and targeted vaccination initiative in response to an outbreak of meningococcal disease among illicit drug users in Brooklyn, New York. Clin Infect Dis. 2009;48:894-901. Medline:19231975 doi:10.1086/597257

42 Bradley K, Smithee L, Clark T, Wu H, Mair R, Harcourt B, et al. Outbreak of meningococcal disease associated with an elementary school - Oklahoma, March 2010. MMWR Morb Mortal Wkly Rep. 2012;61:217-21. Medline:22475849

43 Duffy J, Johnsen P, Ferris M, Miller M, Leighton K, McGilvray M, et al. Safety of a meningococcal group B vaccine used in response to two university outbreaks. J Am Coll Health. 2017;65:380-8. Medline:28362241 doi:10.1080/074484 81.2017 .1312418

44 McNamara LA, Shumate AM, Johnsen P, MacNeil JR, Patel M, Bhavsar T, et al. First use of a serogroup b meningococcal vaccine in the US in response to a university outbreak. Pediatrics. 2015;135:798-804. Medline:25917990 doi:10.1542/ peds.2014-4015 
45 Ryan J, Douglass J. Meningitis, meningococcal - USA: (OR) college, sg B, sg B vaccine, RFI ProMED mail. Archive Number: 20170305.4881298.

46 Gorrow C. Meningitis, meningococcal - USA: (OR) fatal, college, sg. B, sg. B vaccine ProMED mail. Archive Number: 20150531.3398946

47 Soeters HM, McNamara LA, Whaley M, Wang X, Alexander-Scott N, Kanadanian KV, et al. Serogroup B Meningococcal Disease Outbreak and Carriage Evaluation at a College - Rhode Island, 2015. MMWR Morb Mortal Wkly Rep. 2015;64:606-7. Medline:26068563

48 Biswas HH, Han GS, Wendorf K, Winter K, Zipprich J, Perti T, et al. Notes from the field: outbreak of Serogroup B meningococcal disease at a university - California, 2016. MMWR Morb Mortal Wkly Rep. 2016;65:520-1. Medline:27227576 doi:10.15585/mmwr.mm6520a3

49 Iser BP, Lima HC, de Moraes C, de Almeida RP, Watanabe LT, Alves SL, et al. Outbreak of Neisseria meningitidis C in workers at a large food-processing plant in Brazil: challenges of controlling disease spread to the larger community. Epidemiol Infect. 2012;140:906-15. Medline:21875453 doi:10.1017/S0950268811001610

50 Gorla MC, de Lemos AP, Quaresma M, Vilasboas R, Marques O, de Sa MU, et al. Phenotypic and molecular characterization of serogroup C Neisseria meningitidis associated with an outbreak in Bahia, Brazil. Enferm Infecc Microbiol Clin. 2012;30:56-9. Medline:22078548 doi:10.1016/j.eimc.2011.07.022

51 Sáfadi MA, Carvalhanas TR, Paula de Lemos A, Gorla MC, Salgado M, Fukasawa LO, et al. Carriage rate and effects of vaccination after outbreaks of serogroup C meningococcal disease, Brazil, 2010. Emerg Infect Dis. 2014;20:806-11. Medline:24751156 doi:10.3201/eid2005.130948

52 Terra. Meningitis, meningococcal - Chile (04): (RM) ProMED mail. Archive Number: 20121118.1414639.

53 Chacon-Cruz E, Espinosa-De Los Monteros LE, Navarro-Alvarez S, Aranda-Lozano JL, Volker-Soberanes ML, Rivas-Landeros RM, et al. An outbreak of serogroup C (ST-11) meningococcal disease in Tijuana, Mexico. Ther Adv Vaccines. 2014;2:71-6. Medline:24790731 doi:10.1177/2051013614526592

54 Chadee DD, Lee R, Ferdinand A, Prabhakar P, Clarke D, Jacob B. Meningococcal meningitis outbreak in Trinidad, 1998. Eur J Gen Med. 2006;3:49-53. doi:10.29333/ejgm/82377

55 Reintjes R, Kistemann T, MacLehose L, McKee M, Gill N, Weinberg J, et al. Detection and response to a meningococcal disease outbreak following a youth football tournament with teams from four European countries. Int J Hyg Environ Health. 2002;205:291-6. Medline:12068748 doi:10.1078/1438-4639-00156

56 Kriz P, Vlckova J, Bobak M. Targeted vaccination with meningococcal polysaccharide vaccine in one district of the Czech Republic. Epidemiol Infect. 1995;115:411-8. Medline:8557072 doi:10.1017/S0950268800058568

57 Rønne T, Berthelsen L, Buhl LH, Lind I. Comparative studies on pharyngeal carriage of Neisseria meningitidis during a localized outbreak of serogroup C meningococcal disease. Scand J Infect Dis. 1993;25:331-9. Medline:8362229 doi: $10.3109 / 00365549309008507$

58 Samuelsson S, Ege P, Berthelsen L, Lind I. An outbreak of serogroup B:15:P1.16 meningococcal disease, Frederiksborg County, Denmark, 1987-9. Epidemiol Infect. 1992;108:19-30. Medline:1547836 doi:10.1017/S0950268800049463

59 Grodet C, Dequin PF, Watt S, Lanotte P, de Gialluly C, Taha MK, et al. Outbreak in France of Neisseria meningitidis B:15:P1.12 belonging to sequence type 1403. Clin Microbiol Infect. 2004;10:845-8. Medline:15355418 doi:10.1111/ j.1469-0691.2004.00935.x

60 Delisle E, Larrieu S, Simoes J, Laylle N, De Pommerol M, Taha MK, et al. Community outbreak of group B meningococcal disease in southwest France-December 2008 to September 2009. Euro Surveill. 2010;15:19665. Medline:20929645

61 Parent du Chatelet I, Barboza P, Taha MK. W135 invasive meningococcal infections imported from Sub-Saharan Africa to France, January to April 2012. Euro Surveill. 2012;17:20181. Medline:22687826

62 Hauri AM, Ehrhard I, Frank U, Ammer J, Fell G, Hamouda O, et al. Serogroup C meningococcal disease outbreak associated with discotheque attendance during carnival. Epidemiol Infect. 2000;124:69-73. Medline:10722132 doi:10.1017/ S0950268899003416

63 Hellenbrand W, Claus H, Schink S, Marcus U, Wichmann O, Vogel U. Risk of Invasive Meningococcal Disease in Men Who Have Sex with Men: Lessons Learned from an Outbreak in Germany, 2012-2013. PLoS One. 2016;11:e0160126. Medline:27486669 doi:10.1371/journal.pone.0160126

64 Makras P, Alexiou-Daniel S, Antoniadis A, Hatzigeorgiou D. Outbreak of meningococcal disease after an influenza B epidemic at a Hellenic Air Force recruit training center. Clin Infect Dis. 2001;33:e48-50. Medline:11512107 doi: $10.1086 / 322609$

65 Ferro A, Baldo V, Cinquetti S, Corziali P, Gallo G, Lustro G, et al. Outbreak of serogroup C meningococcal disease in Veneto region, Italy. Euro Surveill. 2008;13:8008. Medline:18445389

66 prensa-latina.cu. Meningitis, meningococcal - Italy: cruise ship, exposure ProMED mail. Archive Number: 20121009.1333637.

67 van der Ende A, Hopman CT, Keijzers WC, Spanjaard L, Lodder EB, van Keulen PH, et al. Outbreak of meningococcal disease caused by PorA-deficient meningococci. J Infect Dis. 2003;187:869-71. Medline:12599063 doi:10.1086/367899

68 Kristiansen BE, Sorensen B, Spanne O, Bjorvatn B. Restriction fingerprinting and serology in a small outbreak of B15 meningococcal disease among Norwegian soldiers. Scand J Infect Dis. 1985;17:19-24. Medline:2986281 doi: $10.3109 / 00365548509070415$

69 Kristiansen BE, Sorensen B, Bjorvatn B, Falk ES, Fosse E, Bryn K, et al. An outbreak of group B meningococcal disease: tracing the causative strain of Neisseria meningitidis by DNA fingerprinting. J Clin Microbiol. 1986;23:764-7. Medline:3084555 
70 Grecki M, Bienias M. Outbreak of invasive meningococcal disease among soldiers in Skwierzyna, Poland, March 2006. Euro Surveill. 2006;11:E060706.4. Medline:16966756

71 Skoczyńska A, Wasko I, Kuch A, Golebiewska A, Forys M, Hryniewicz W. Outbreak of invasive meningococcal disease in Goleniow County, northwest Poland, March 2009. Euro Surveill. 2010;15:19646. Medline:20807486 doi:10.2807/ ese.15.34.19646-en

72 Saez Nieto JA, Perucha M, Llacer A. Outbreak of meningococcal infection caused by Neisseria meningitidis Group C type 2 in a nursery. Med Trop. 1983;43:49-51.

73 Camps N, Follia N, Berrón S, De La Fuente L, Vázquez JA. An outbreak of invasive meningococcal disease probably associated with an indoor swimming pool. Clin Microbiol Infect. 1998;4:349-50. doi:10.1111/j.1469-0691.1998.tb00072.x

74 Smith-Palmer A, Oates K, Webster D, Taylor S, Scott KJ, Smith G, et al. Outbreak of Neisseria meningitidis capsular group W among scouts returning from the World Scout Jamboree, Japan, 2015. Euro Surveill. 2016;21:30392. Medline:27918267 doi:10.2807/1560-7917.ES.2016.21.45.30392

75 Easton DM, Estcourt PG, Brimblecombe FS, Burgess W, Hass L, Kurtz JB. Outbreak of meningococcal disease in Devon. BMJ. 1974;1:507-9. Medline:4206129 doi:10.1136/bmj.1.5906.507

76 Round A, Evans MR, Salmon RL, Hosein IK, Mukerjee AK, Smith RW, et al. Public health management of an outbreak of group C meningococcal disease in university campus residents. Eur J Public Health. 2001;11:431-6. Medline:11766486 doi:10.1093/eurpub/11.4.431

77 Irwin DJ, Miller JM, Milner PC, Patterson T, Richards RG, Williams DA, et al. Community immunization programme in response to an outbreak of invasive Neisseria meningitidis serogroup C infection in the Trent region of England 1995-1996. J Public Health Med. 1997;19:162-70. Medline:9243431 doi:10.1093/oxfordjournals.pubmed.a024604

78 Gilmore A, Jones G, Barker M, Soltanpoor N, Stuart JM. Meningococcal disease at the University of Southampton: outbreak investigation. Epidemiol Infect. 1999;123:185-92. Medline:10579436 doi:10.1017/S0950268899002794

79 Stewart A, Coetzee N, Knapper E, Rajanaidu S, Iqbal Z, Duggal H. Public health action and mass chemoprophylaxis in response to a small meningococcal infection outbreak at a nursery in the West Midlands, England. Perspect Public Health. 2013;133:104-9. Medline:23467531 doi:10.1177/1757913912439928

80 Chatt C, Gajraj R, Hawker J, Neal K, Tahir M, Lawrence M, et al. Four-month outbreak of invasive meningococcal disease caused by a rare serogroup B strain, identified through the use of molecular PorA subtyping, England, 2013. Euro Surveill. 2014;19:20949. Medline:25394258 doi:10.2807/1560-7917.ES2014.19.44.20949

81 Nair D, Dawar R, Deb M, Capoor MR, Singal S, Upadhayay DJ, et al. Outbreak of meningococcal disease in and around New Delhi, India, 2005-2006: a report from a tertiary care hospital. Epidemiol Infect. 2009;137:570-6. Medline:18840317 doi:10.1017/S0950268808001398

82 Ongoing outbreak of meningococcal disease in India. Euro Surveill. 2005;10:E050602.2. Medline:16783091

83 Duggal S, Duggal N, Charoo H, Mahajan RK. Recent outbreak of meningococcal meningitis-a microbiological study with brief review of literature. J Commun Dis. 2007;39:209-16. Medline:18697589

84 Kushwaha AS, Aggarwal SK, Arora MM. Outbreak of Meningococcal Infection amongst Soldiers Deployed in Operations. Med J Armed Forces India. 2010;66:4-8. Medline:27365694 doi:10.1016/S0377-1237(10)80082-6

85 Almog R, Block C, Gdalevich M, Lev B, Wiener M, Ashkenazi S. First recorded outbreaks of meningococcal disease in the Israel Defence Force: three clusters due to serogroup $C$ and the emergence of resistance to rifampicin. Infection. 1994;22:69-71. Medline:8070932 doi:10.1007/BF01739006

86 al-Gahtani YM, el Bushra HE, al-Qarawi SM, al-Zubaidi AA, Fontaine RE. Epidemiological investigation of an outbreak of meningococcal meningitis in Makkah (Mecca), Saudi Arabia, 1992. Epidemiol Infect. 1995;115:399-409. Medline:8557071 doi:10.1017/S0950268800058556

87 Pearce MC, Sheridan JW, Jones DM, Lawrence GW, Murphy DM, Masutti B, et al. Control of group C meningococcal disease in Australian aboriginal children by mass rifampicin chemoprophylaxis and vaccination. Lancet. 1995;346:203. Medline:7603139 doi:10.1016/S0140-6736(95)92651-8

88 Jelfs J, Jalaludin B, Munro R, Patel M, Kerr M, Daley D, et al. A cluster of meningococcal disease in western Sydney, Australia initially associated with a nightclub. Epidemiol Infect. 1998;120:263-70. Medline:9692605 doi:10.1017/ S0950268898008681

89 Zhang J, Zhou HJ, Xu L, Hu GC, Zhang XH, Xu SP, et al. Molecular characteristics of Neisseria meningitidis isolated during an outbreak in a jail: association with the spread and distribution of ST-4821 complex serogroup C clone in China. Biomed Environ Sci. 2013;26:331-7. Medline:23611126

90 Mills C, Sexton K, Carter P. Unanswered questions, the epidemiology of a community outbreak: meningococcal C disease in Northland, New Zealand, 2011. N Z Med J. 2013;126:40-5. Medline:23797075

91 Taiwan Centers for Disease Control. Meningitis, meningococcal - Taiwan: fatal, military base ProMED mail. Archive Number: 20170801.5218924.

92 Abio A, Neal KR, Beck CR. An epidemiological review of changes in meningococcal biology during the last 100 years. Pathog Glob Health. 2013;107:373-80. Medline:24392681 doi:10.1179/2047773213Y.0000000119

93 Holst J, Oster P, Arnold R, Tatley MV, Nćss LM, Aaberge IS, et al. Vaccines against meningococcal serogroup B disease containing outer membrane vesicles (OMV): Lessons from past programs and implications for the future. Hum Vaccin Immunother. 2013;9:1241-53. Medline:23857274 doi:10.4161/hv.24129

94 Soeters HM, Dinitz-Sklar J, Kulkarni PA, MacNeil JR, McNamara LA, Zaremski E, et al. Serogroup B Meningococcal Disease vaccine recommendations at a university, New Jersey, USA, 2016. Emerg Infect Dis. 2017;23:867. Medline:28418307 doi:10.3201/eid2305.161870 
95 Trotter CL, Lingani C, Fernandez K, Cooper LV, Bita A, Tevi-Benissan C, et al. Impact of MenAfriVac in nine countries of the African meningitis belt, 2010-15: an analysis of surveillance data. Lancet Infect Dis. 2017;17:867-72. Medline:28545721 doi:10.1016/S1473-3099(17)30301-8

96 LaForce FM, Djingarey M, Viviani S, Preziosi MP. Successful African introduction of a new Group A meningococcal conjugate vaccine: Future challenges and next steps. Hum Vaccin Immunother. 2018;14:1098-102. Medline:28968148 doi:10.1080/21645515.2017.1378841

97 Palmgren H. Meningococcal disease and climate. Glob Health Action. 2009;2. doi:10.3402/gha.v2i0.2061. Medline:20052424

98 Paireau J, Chen A, Broutin H, Grenfell B, Basta NE. Seasonal dynamics of bacterial meningitis: a time-series analysis. Lancet Glob Health. 2016;4:e370-7. Medline:27198841 doi:10.1016/S2214-109X(16)30064-X

99 Harrison LH, Kreiner CJ, Shutt KA, Messonnier NE, O'Leary M, Stefonek KR, et al. Risk factors for meningococcal disease in students in grades 9-12. Pediatr Infect Dis J. 2008;27:193-9. Medline:18277925 doi:10.1097/INF.0b013e31815c$1 b 3 a$

100 European Centre for Disease Prevention and Control. Invasive meningococcal disease - Annual Epidemiological Report 2016 [2014 data]. Available: https://ecdc.europa.eu/en/publications-data/invasive-meningococcal-disease-annual-epidemiological-report-2016-2014-data. Accessed: 18 December 2017.

101 Harrison LH, Pass MA, Mendelsohn AB, Egri M, Rosenstein NE, Bustamante A, et al. Invasive meningococcal disease in adolescents and young adults. JAMA. 2001;286:694-9. Medline:11495619 doi:10.1001/jama.286.6.694

102 Borrow R, Caugant DA, Ceyhan M, Christensen H, Dinleyici EC, Findlow J, et al. Meningococcal disease in the Middle East and Africa: Findings and updates from the Global Meningococcal Initiative. J Infect. 2017;75:1-11. Medline:28455205 doi:10.1016/j.jinf.2017.04.007

103 Murray J, Agócs M, Serhan F, Singh S, Deloria-Knoll M, O’Brien K, et al. Global invasive bacterial vaccine-preventable diseases surveillance — 2008-2014. MMWR Morb Mortal Wkly Rep. 2014;63:1159-62. Medline:25503919

104 Dbaibo G, Tatochenko V, Wutzler P. Issues in pediatric vaccine-preventable diseases in low- to middle-income countries. Hum Vaccin Immunother. 2016;12:2365-77. Medline:27322436 doi:10.1080/21645515.2016.1181243

105 Berkley JA, Mwangi I, Ngetsa CJ, Mwarumba S, Lowe BS, Marsh K, et al. Diagnosis of acute bacterial meningitis in children at a district hospital in sub-Saharan Africa. Lancet. 2001;357:1753-7. Medline:11403812 doi:10.1016/S01406736(00)04897-2 